\title{
Environmental assessment of the industrial region growth points in the Ural Federal District area
}

\author{
Svetlana Aupova ${ }^{1, *}$ and Elena Silova ${ }^{1}$ \\ ${ }^{1}$ Chelyabinsk State University, 129, Br.Kashirinykh str., 454001, Chelyabinsk, Russia
}

\begin{abstract}
The article deals with the diversification of the regional economy and searching for new drivers and growth points. The purpose of the work is to analyze the state and development of the regional economy using the example of the Ural Federal District's regions and identify their potential growth points. The information base of the study is regional statistics provided by the Federal Statistics Service of Russia. The study used methods of statistical analysis, in particular, dynamics analysis and correlation analysis. The analysis of the leading indicators characterizing the development of the regional economy is carried out: the sectoral structure of the GRP, the index of industrial production, the level of scientific and technological development, and per capita income.
\end{abstract}

\section{Introduction}

In modern conditions, when Russia is in a state of choosing strategic development and further behavior model, which should and could ensure economic growth, it is necessary to search, identify and activate points of growth of the regional economy. Currently, great attention is paid to the region's socio-economic development, analysis of the regional structure's effectiveness, and identification of growth points in the regions.

The development of the theory of points and poles of growth is associated with the name of the French researcher François Perroux, who in 1970 suggested that growth does not occur instantly but spreads from more developed territories to peripheral ones, while growth points can stimulate growth in other parts of space, an essential role in innovation plays into it. The existence of growth poles is due to objective reasons [14]. Perroux's ideas were developed in the works of his student J. Boudville, who believes that "a regional growth pole is a set of developing and expanding industries located in an urbanized zone and capable of causing further development of economic activity in the entire zone of its influence" [22].

Today, the theory of polarized economic growth is reflected in the works of Russian researchers M.V. Glazyrina, S.Yu. Glazieva, A.P. Sysoeva, K.V. Pavlov, A.V. Suvorova. Yu.V. Perevalov and others $[5,6,12,13,17]$.

S. Raevsky, Y. Isachenko emphasize the variety of interpretations of the definition of the essence of "growth points" and believe that growth points can be understood as

${ }^{*}$ Corresponding author: s-aupova@mail.ru 
territories, industries, and enterprises. These scientists propose the following definition of the growth point of the region - "this is a large enterprise in a specific industry or a set of economic entities within a certain territory, which have significant potential for selfdevelopment and can provide high dynamics of economic growth in the region" [16]. A.S. Vanyushkin and S.V. Druzin emphasize the importance of such an aspect of developing growth points as their sustainability [4].

I.I. Lyashenko lists the leading indicators that can be used to identify points of growth: the share of the industry in the total volume of manufactured products; the share of unprofitable enterprises in the industry; the level of profitability of the industry; profit in the industry; budget efficiency (tax payments) and some others [11].

A.V. Suvorov's research shows that the formation of growth poles can have negative consequences for neighboring regions. The author also draws attention to the ever-growing differentiation of Russian regions and the need for a balanced regional policy [17].

M.G. Kovalenko gives the following definition of diversification - "the simultaneous development of many production types that are not related to each other, the expansion of the range of products and services produced, and a diversified regional economy is a comprehensively developed, relatively resistant to economic crises, diversified economy." The processes of diversification of the regional economy intensify intra- and interregional competition, while each region has its limit to diversification [9].

Besides, a large number of leading researchers assert the importance of identifying growth points. Thus, N. Dobretsov, A. Kontorovich, V. Kuleshova note the ability of growth points to provide sustainable development of the regional economy and contribute to many social problems. The identification and development of these points allow increasing budget revenues, gross regional product, and getting new additional jobs [7].

Bekbergeneva D.E. believes that those industries with a higher intellectual potential can become growth points [2]. According to this author, the digitalization of the regional economy is of great importance in using the regions' growth points.

Zharov A.V., Tkachenko A.O. note that the current crisis phenomena in the economy raise the question of changing regional development paradigm from equalizing to stimulating. The author sees scientific and technological development and financial assets as the main factors for regional economies' growth. The authors see clusters' development as the primary approach, while he suggests using the following methods of supporting clusters: grants and subsidies, preferential taxation, adjusting strategic programs to develop territories [8].

A.B. Krylovsky argues that "underutilization of natural and human resources" leads to an increase in regional imbalances and also gives rise to the existence of depressed regions. He also notes that the main driver in the development of points of growth in the region can be innovation and investment projects, as well as financial investments in the economy [10].

Urunov A.A., Avezova M.M., Nazimova M.A. developed an author's method for determining points and growth poles. According to the authors, the main criterion for identifying a growth point is the multiplier effect. These authors also develop the concept of growth poles. In their opinion, the growth pole demonstrates stable growth rates and occupies a significant part in the sectoral structure, and can become the locomotives of the regional economy's development [21]. Polyanin A.V., Pronyaeva L.I. give an extended list of criteria for determining growth points. Growth points affect the growth of the gross regional product; production at growth points can be oriented towards foreign markets, they can provide an inflow of investments into the region and solve the problem of increasing the region's population's well-being [15].

There are separate studies on growth points in individual regions. Bulatova N.N., Alekseeva V.V. conducted a study of the Republic of Buryatia's development opportunities 
using the SWOT analysis method and the cluster approach. The authors identified six main economic zones in the region, one of the most significant growth points, researchers call the development of an integrated transport system [3].

\section{Materials and methods}

The authors selected the regions of the Ural Federal District as the object of research. Most of these regions are industrial. Considerable attention is paid to the analysis of the features of industrial regions' development in the domestic economic literature. For example, D.S. Benz and E.S. Silova systematize the concepts and highlight the primary indicators that characterize the industrial region. In their work, they investigate the relationship of indicators such as gross regional product, the share of industrial production, budget revenues, life expectancy, thus combining various aspects of regional development, including social ones [1]. According to the famous Russian scientist A.I. Tatarkin, the Ural region has a diverse resource potential, a vast range of manufactured industrial products, a developed transport infrastructure. This region is a connecting region and can become a catalyst for forming a single economic space and a mega-technopolis [19, 20].

During the Ural Federal District study, it was found that this district is located in a favorable natural and climatic zone with a predominance of the following types of industry: metallurgy, mechanical engineering, woodworking, and chemical production. It should be noted that, with the activation of growth points, there is an opportunity, in our opinion, to adhere to one of two approaches. Firstly, provided that the available socio-economic, climatic, and other possibilities of the region are not fully utilized, it is assumed that the available labor force will be involved in increasing incomes, increasing the gross region of the product, and solvency. This approach involves using an extensive type of growth, which allows to build up various types of resources but up to a certain point.

The second approach assumes that the region has used all available resources in total. In this case, the search and activation of growth points are possible from using new technologies, introducing innovative techniques and methods of manufacturing products at existing enterprises that are undergoing reconstruction. With this approach, the synergistic effect from the intensive and innovative type of economic growth will be used. In this case, it is possible to achieve an increase in labor productivity and overall production efficiency. However, when using this approach, the use of investment resources becomes inevitable. Besides, this approach is quite challenging to implement and requires significant capital investments. The use of this approach in practice implies the presence of a well-developed scientific potential of the territory in the field of science-intensive, information, and macrotechnologies. An important aspect is that its use does not give a quick result, and the need for implementation should come both from the state, supported by the legislative framework, and from the enterprises themselves, which, as a rule, is not a priority task for them. However, the new reality presupposes the fastest and not painless transition to the second approach.

\section{Results}

At the first stage of our study, we will consider the leading indicators characterizing the Ural Federal District's regions' economy according to the Federal Statistics Service of the Russian Federation. These indicators will allow us to identify critical trends in developing the Ural Federal District's regional economies. In fig. 1 shows data on the index of the physical volume of GRP for 2010-2017. 


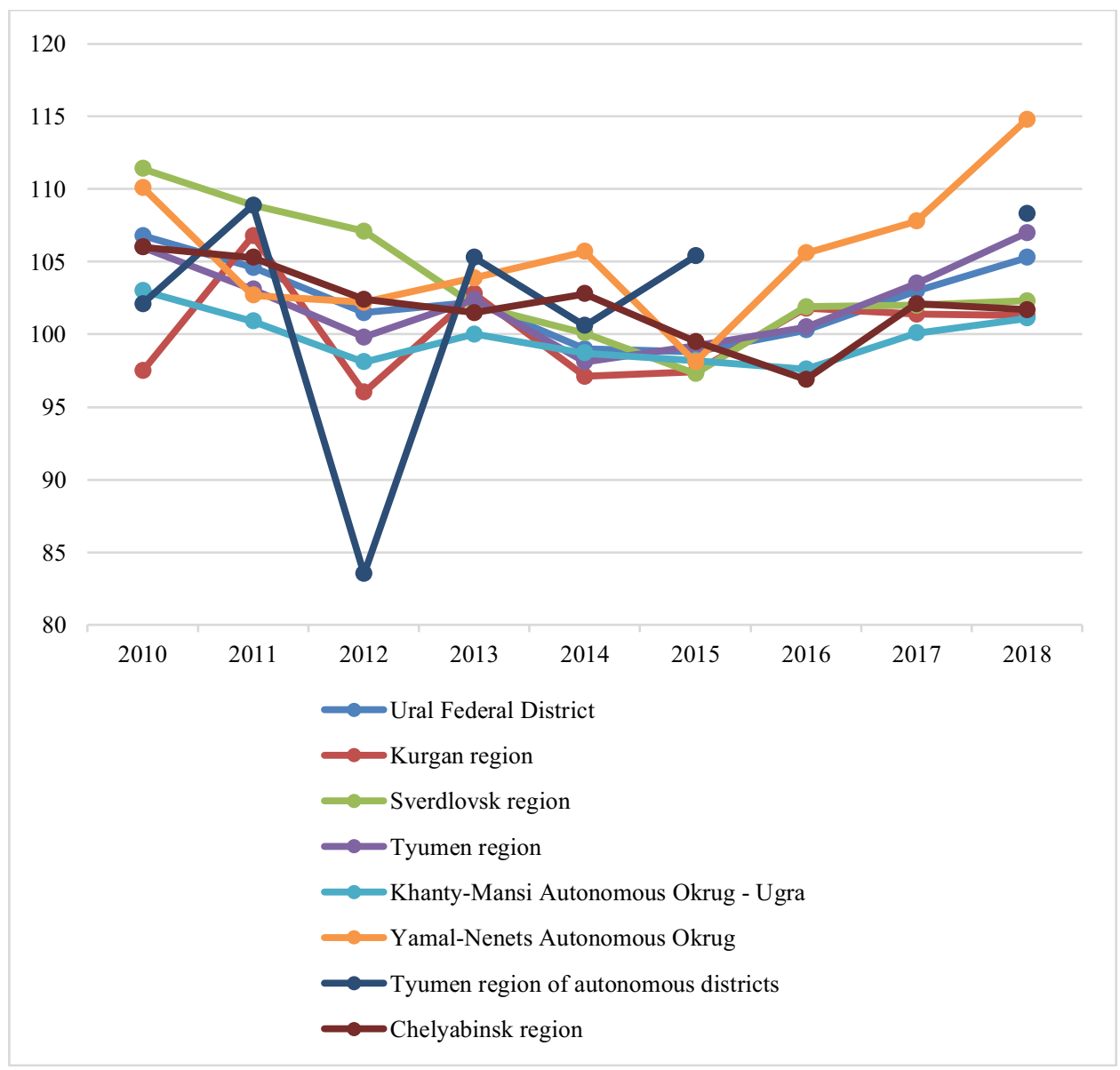

Fig. 1 Index of physical volume of gross regional product (in constant prices; as a percentage of the previous year). Source: Regions of Russia. Socio-economic indicators. 2019. Statistical collection // gks.ru (date of treatment 09/10/2020).

As we can see from Table 1, the most crisis years are 2014 and 2015, when there is a decrease within $3 \%$ of the physical volume of GRP in most regions. In our opinion, this is primarily to the introduction of economic sanctions and the onset of crisis phenomena in the Russian economy. Since 2016, the GRP growth has been recovering, but so far, it is insignificant, except for the Yamalo-Nenets Autonomous Okrug (almost 8\%). On average, in the Ural Federal District for the period under review from 2010 to 2018, one can note low growth rates - at the level of $2-3.5 \%$. In the Chelyabinsk Region, the most significant decrease - by more than $3 \%$ was recorded in 2016 , which is associated with a time lag in response to changes in economic policy in 2014. In 2017, there is a slight increase in the gross regional product by $2 \%$. This also allows us to note that the use of the first approach has not reached its maximum. Next, we will consider the indicators characterizing the dynamics of investments since the renewal of production assets, in our opinion, is also one of the most important drivers of economic growth. The data are shown in Fig. 2. 


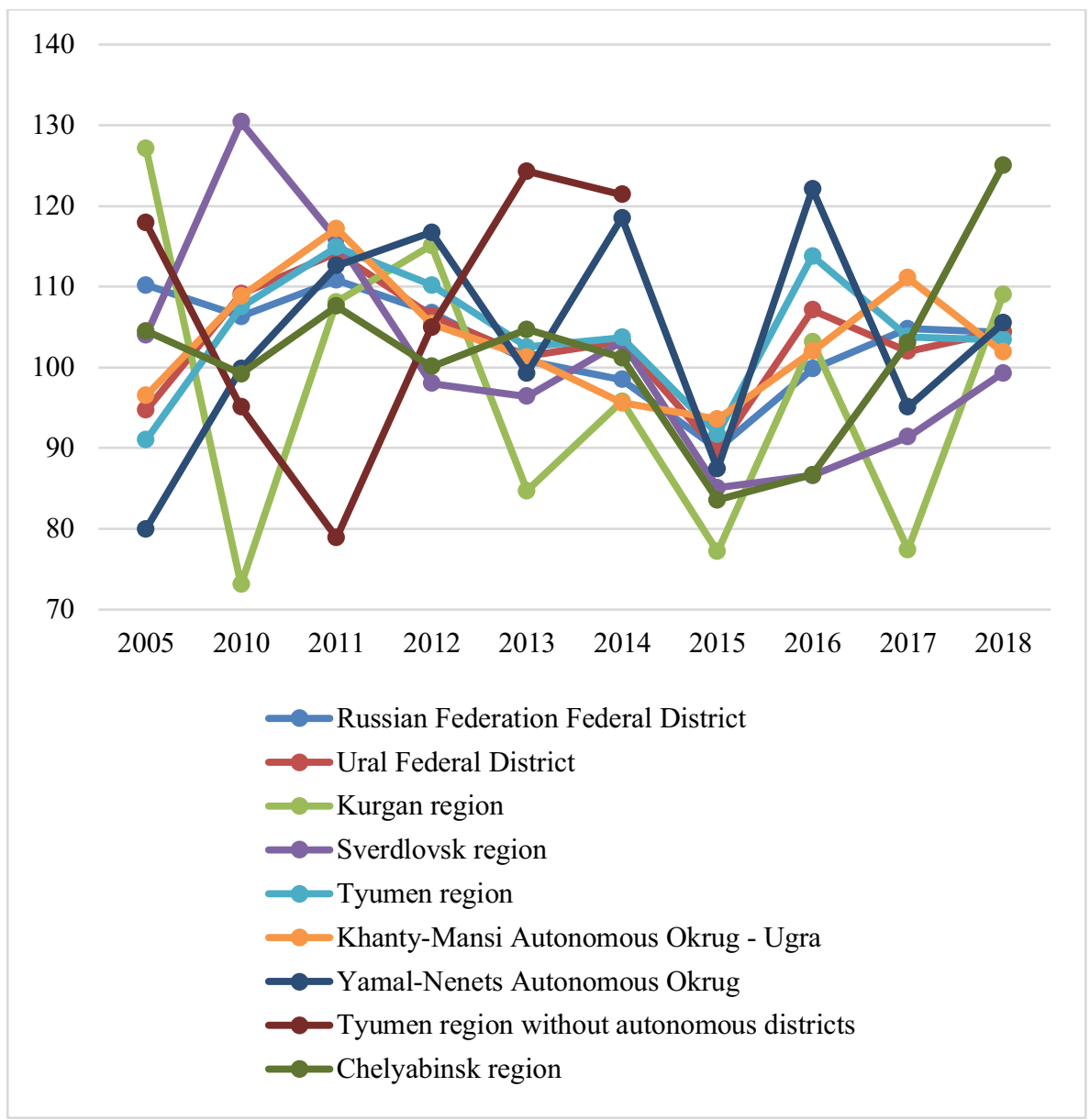

Fig. 2. Index of the physical volume of investments in fixed assets in the regions of the Ural Federal District,\% (in comparable prices; as a percentage of the previous year). Source: Regions of Russia. Socio-economic indicators. 2019. Statistical collection // gks.ru (date of treatment 09/10/2020).

The fall in investment was more significant than the decline in GRP. So, in the Sverdlovsk region, the decline was recorded in 6 periods, the maximum - about $15 \%$ in 2015, the recovery has not yet occurred. In the Chelyabinsk Region, the decline occurred in 2010, 2015 and 2016, but in 2018 there was an increase of $25 \%$. The most negligible decline was the investment in the Tyumen region. In the Kurgan region, the maximum decline is recorded - by almost $23 \%$. This situation impedes the second approach's application and proves the assumption that enterprises are not ready to fully switch to the second approach3, provided that the available resources are underutilized. The next significant issue to consider is the structure of investments. In fig. 3 shows the structure of investments by types of fixed assets. 


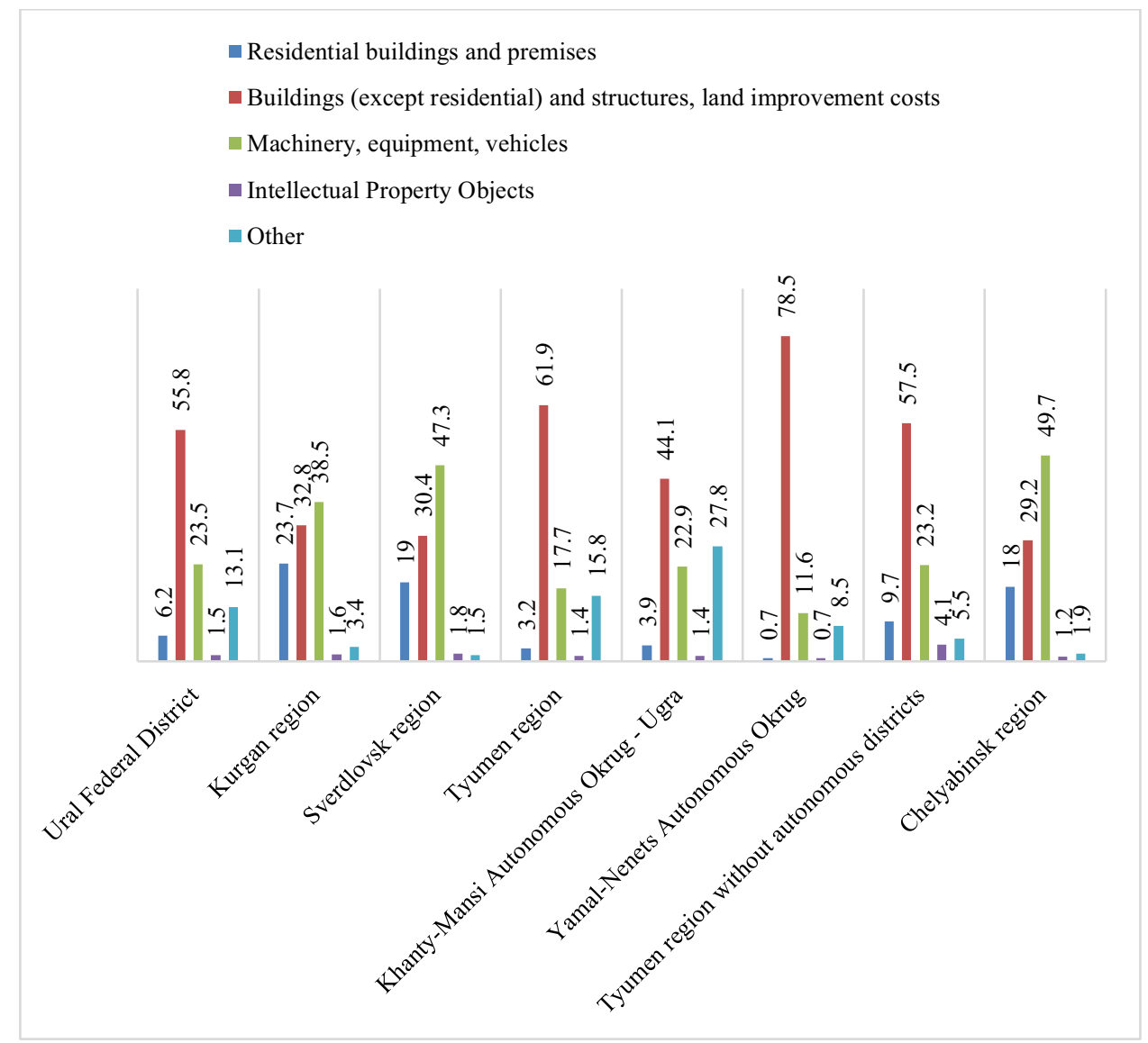

Fig. 3. Structure of investments in fixed assets by types of fixed assets in 2017,\%. Source: Regions of Russia. Socio-economic indicators. 2019. Statistical collection // gks.ru (date of treatment 09/10/2020).

In the Chelyabinsk and Kurgan regions, a large share (18 and 23.7\%, respectively) in the structure of investments is occupied by housing construction. The main share of investments - almost 50\% - in the Chelyabinsk region falls on machinery and equipment. The same trend is observed in the Sverdlovsk region. In the Tyumen region and autonomous okrugs, the leading share of investments falls on industrial buildings (almost $80 \%$ in YAMAO). A negative trend, in our opinion, is the low rates of investments in intellectual property (and these are innovations) - an average of $1.5 \%$ in the district, the largest share - just over $4 \%$ in the Tyumen region.

Thus, the study proves that the first approach cannot be discounted since the available resources and opportunities have not reached their maximum. However, it should be noted that, unfortunately, the scientific and technological development of the territories cannot be uniform in any way. The willingness to develop within the framework of the second approach may appear in the regions as a spontaneous factor that will make it possible to modernize existing resources and use them in the future as a competitive advantage. This can lead to even greater differentiation of the socio-economic development of Russian regions, which is a negative factor, but in our opinion, this trend is not long-term. We must not forget that when using this approach, the speed of activation of growth points depends on the effectiveness of interaction between science, business, and government. If there are at least two points of growth, the territories between them are automatically subject to the 
need for modernization and (or) further development, which leads to the emergence of new drivers in development.

To identify the region's growth points, it is also necessary to analyze the sectoral structure of the economy, which is presented. Let us consider the sectoral structure of the GRP of the regions of the Ural Federal District. The data are presented in Table. 1.

Table. 1 Sectoral structure of GRP by region of UrFo in 2017,\%. Source: Regions of Russia. Socioeconomic indicators. 2019. Statistical collection // gks.ru (date of treatment 09/10/2020).

\begin{tabular}{|c|c|c|c|c|c|c|}
\hline Industries & 逽 & 望 & 总 & 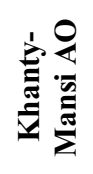 & 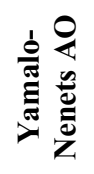 & 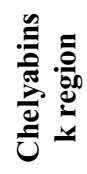 \\
\hline $\begin{array}{l}\text { Agriculture, forestry, hunting, } \\
\text { fishing and fish farming }\end{array}$ & 11.1 & 2.4 & 0.7 & 0.3 & 0.1 & 6.1 \\
\hline Mining & 0.9 & 1.5 & 57.4 & 67.1 & 61.1 & 2.1 \\
\hline Manufacturing & 21.2 & 31 & 4.2 & 2.4 & 1.6 & 35.3 \\
\hline $\begin{array}{l}\text { Provision of electric energy } \\
\text { with gas and steam; air } \\
\text { conditioning }\end{array}$ & 7.5 & 4.4 & 2.3 & 2.7 & 1.5 & 4.1 \\
\hline $\begin{array}{l}\text { Water supply; water disposal } \\
\text { organization of waste failure } \\
\text { and disposal, pollution } \\
\text { disposal activities }\end{array}$ & 0.8 & 0.9 & 0.3 & 0.3 & 0.1 & 1.1 \\
\hline Construction & 3.9 & 4.2 & 9.9 & 6.4 & 15.4 & 5.3 \\
\hline $\begin{array}{l}\text { Wholesale and retail trade; } \\
\text { repair of motor vehicles } \\
\text { and motorcycles }\end{array}$ & 10 & 17.1 & 5.6 & 2.8 & 6.2 & 11.7 \\
\hline Transportation and Storage & 11.1 & 8.7 & 6.3 & 6.6 & 4.7 & 7.1 \\
\hline $\begin{array}{l}\text { Activities of hotels and public } \\
\text { catering enterprises }\end{array}$ & 0.9 & 1.1 & 0.5 & 0.5 & 0.3 & 0.7 \\
\hline $\begin{array}{l}\text { Information and } \\
\text { communications activities }\end{array}$ & 3 & 2.5 & 0.7 & 0.6 & 0.4 & 2 \\
\hline $\begin{array}{lll}\begin{array}{l}\text { Financial and } \\
\text { activities }\end{array} & & \\
\end{array}$ & 0.2 & 0.3 & 0.1 & 0.1 & 0 & 0.3 \\
\hline Real estate activities & 4.5 & 6.4 & 1.8 & 1.5 & 1 & 6 \\
\hline $\begin{array}{l}\text { Professional, scientific and } \\
\text { technical activities }\end{array}$ & 1.5 & 3.9 & 2.1 & 0.8 & 0.7 & 3.7 \\
\hline $\begin{array}{ll}\text { Administrative } & \text { activities and } \\
\text { related } & \text { supplementary } \\
\text { services } & \\
\end{array}$ & 2.2 & 3.2 & 2.7 & 2.6 & 3.2 & 1.5 \\
\hline $\begin{array}{llr}\text { Public } & \text { administration and } \\
\text { military } & \text { security; social and } \\
\text { military } & \text { security; social } \\
\text { security } & & \end{array}$ & 8.3 & 4.5 & 1.8 & 1.6 & 1.5 & 4.3 \\
\hline Education & 4.7 & 2.9 & 1.4 & 1.4 & 0.8 & 3.2 \\
\hline $\begin{array}{l}\text { Health and social services } \\
\text { activities }\end{array}$ & 7 & 3.8 & 1.8 & 1.9 & 1.2 & 4.5 \\
\hline $\begin{array}{l}\text { Cultural, sports, leisure and } \\
\text { entertainment activities }\end{array}$ & 0.8 & 0.6 & 0.3 & 0.3 & 0.2 & 0.6 \\
\hline Provision of other services & 0.4 & 0.6 & 0.1 & 0.1 & 0 & 0.4 \\
\hline $\begin{array}{l}\text { Activities of households as } \\
\text { employers }\end{array}$ & 0 & 0 & 0 & 0 & 0 & 0 \\
\hline
\end{tabular}

In the GRP structure of three regions - the Tyumen region and the autonomous okrugs, 
mining prevails - about $60 \%$. The manufacturing industry is most developed in the Sverdlovsk and Chelyabinsk regions - more than 30\%, mainly metallurgy and mechanical engineering, since these regions are old industrial. Agriculture is most developed in the Kurgan region, where it accounts for more than $11 \%$ of the GRP, followed by the Chelyabinsk region with a significantly lower share of $6.1 \%$, but agriculture in this region can be considered as a potential growth point. Trading activity is most developed in the Sverdlovsk region $-17 \%$, in the Chelyabinsk region $-11.7 \%$ and ranks second in economic sectors' structure. Trade occupies an important place in the economy of the Sverdlovsk region $-17 \%$ and is the second most important industry in the economy of this region, in other regions the role of trade is much less (at the level of 5-6\%), it is also developed in the Chelyabinsk region (11.7\%) and Tyumen region (13.6\%). An essential industry in the Tyumen region is scientific activity (occupies 10.5\%), which is not typical for other Ural Federal District regions (on average 2-3\%). The same substantial variation can be noted in some other industries, for example, in education - the level varies from 0.8 in the YamaloNenets Autonomous Okrug to 3 and 3.2\% in the Tyumen and Chelyabinsk regions, which are leaders. Almost all of the Ural regions are insignificant in such industries as finance and insurance, hotels and catering, information and communications. In general, from the standpoint of the sectoral structure, in almost all regions, there are basic, most developed, and prevailing sectors in the structure of the economy, so it is not easy to talk about the diversification of the Ural regional economies.

An essential indicator of the standard of living as the ultimate goal of economic growth and development is cash income per capita. Data for 2016-2019 are presented in table 2

Table 2. Cash income per capita, ruble Source: Regions of Russia. Socio-economic indicators. 2019. Statistical collection // gks.ru (date of treatment 09/10/2020).

\begin{tabular}{|c|c|c|c|c|}
\hline Region & $\mathbf{2 0 1 6}$ & $\mathbf{2 0 1 7}$ & $\mathbf{2 0 1 8}$ & $\mathbf{2 0 1 9}$ \\
\hline Russian Federation & 46.102 & 44.756 & 47.643 & 40.876 \\
\hline Ural federal district & 42.665 & 43.938 & 47.623 & 40.504 \\
\hline Kurgan region & 24.203 & 26.092 & 27.622 & 24.157 \\
\hline Sverdlovsk region & 45.028 & 48.050 & 52.706 & 44.377 \\
\hline Tyumen region & 56.783 & 56.292 & 60.442 & 51.356 \\
\hline Tyumen region without AO & 41.911 & 41.975 & 45.929 & 33.413 \\
\hline Khanty-Mansi Autonomous Okrug & 58.138 & 56.263 & 61.437 & 56.627 \\
\hline Chelyabinsk region & 29.706 & 30.297 & 32.618 & 27.993 \\
\hline Yamal-Nenets Autonomous Okrug & 93.160 & 95.855 & 97.774 & 85.480 \\
\hline
\end{tabular}

Consider the data presented in Table 1. As we can see, during the observed period, average per capita income decreased by more than two thousand rubles on average in the regions of the Ural Federal District, in the Russian Federation, the decrease was more significant and amounted to 5,226 rubles. Thus, the average per capita income in the Ural regions practically reached the average Russian level in 2019 (less by 372 rubles). Simultaneously, it should be noted that there is an extreme differentiation in income within the regions. The lowest incomes are in the Kurgan region, and they practically did not change over the period under review and amounted to 24,154 in 2019, which is almost two times less than the average per capita income in the Tyumen region (51,356 rubles). The maximum revenues are typical for the Yamalo-Nenets Autonomous Okrug, but they have also significantly decreased (by more than $8 \%$ ) due to the economic crisis. In our opinion, an important issue remains the income decline in 2020, when employees have lost jobs or were at home due to pandemics. 


\section{Conclusion}

Thus, summing up the consideration of the main economic indicators of the Ural Federal District's regions, we will draw the following brief conclusions about trends in regional economies. The structure of the economies of the main regions is not entirely efficient. Extractive industries (in the Tyumen region's autonomous districts) and manufacturing industries (Chelyabinsk and Sverdlovsk regions) prevail. The services, education, financial, and services sectors in the communications industry are underdeveloped. In recent years, the economies have been experiencing crisis phenomena, which is shown by the decline in the industrial production index and the decline in the population's average per capita income. Some regions are large educational centers (Tyumen, Sverdlovsk and Chelyabinsk regions). Therefore, in our opinion, education can be considered as a point of growth of regional economies. Unfortunately, only in the second group of regions in terms of the level of innovation (medium-strong innovators) is the Chelyabinsk region, the situation is slightly better in the Tyumen region (11th place and the Sverdlovsk region (14th place). Another negative trend can also be noted - a fairly high level of differentiation regions of the Okrug in terms of income (the income gap is more than two times, the most impoverished region is the Kurgan region.) In our opinion, the exciting development of the considered regions requires a clear economic policy to develop growth points and obtain a multiplier effect from them.

In the context of globalization, an unstable geopolitical situation, the question of finding new drivers, points of growth in the development of the regional economy, contributing to the strengthening of the Russian economy as a whole, arises. The interaction between business science and power is becoming a tandem contributing to a complete definition of these positions. However, the territories are not ready for significant transformations until they have exhausted the available opportunities, which sharply hinders the regional economies' growth opportunities.

\section{References}

1. V.I. Barkhatov, D.S. Bents, Ye.S. Silova, Vestnik Chelyabinskogo gosudarstvennogo universiteta 10(406), 26-36 (2017)

2. D.Ye. Bekbergeneva, Ekonomika i biznes: teoriya i praktika 3-1(61), 27-29 (2020)

3. N.N. Bulatova, V.V. Alekseyeva, Vestnik VSGTU 1(32), 72-77 (2011)

4. A.S. Vanyushkin, S.V. Druzin, Geopolitika i ekogeodinamika regionov 5(15).1, 68-77 (2019)

5. M.V. Glazyrin, Proizvodstvenno-sotsial'nyye kompleksy i upravleniye imi (M. Novgorod, 1997)

6. S.Y. Glaz'yev, Teoriya dolgosrochnogo tekhniko-ekonomicheskogo razvitiya (VlaDar, M., 1993)

7. N. Dobretsov, A. Kontorovich, V. Kuleshov, Strategicheskiye tochki rosta i problemy gosudarstvennoy znachimosti $v$ Sibiri i Dal'nem Vostoke, http://www.sbras.nsc.ru

8. A.V. Zharov, A.O. Tkachenko, Interekspo Geo-Sibir' 5, 200-206 (2019)

9. M.G. Kovalenko, Vestnik Adygeyskogo gosudarstvennogo universiteta. Seriya 5: Ekonomika 4(111), 63-67 (2012)

10. A.B. Krylovskiy, Aktual'nyye ekonomicheskiye problemy Yuga Rossii. Regional'naya investitsionnaya politika $v$ mekhanizme stimulirovaniya (na primere proyekta «investitsionnaya politika Stavropol'skogo kraya»), http://www.pn.pglu.ru. 
11. A.Y. Lyashenko, Ekonomicheskiy vestnik Donbassa 3(41), 91-101 (2015)

12. K.V. Pavlov, M.I. Shishkin, Teoriya yadra yadra (Udmurtiya, Izhevsk, 1996)

13. Y.V. Perevalov, I.M. Golova, A.F. Sukhovey, Innovatsionnaya politika v regione: organizatsionno pravovyye aspekty (Institut ekonomiki UrO RAN, Yekaterinburg, 1996)

14. F. Perru, Prostranstvennaya ekonomika 2 (2011)

15. A.V. Polyanin, L.I. Pronyayeva, Region: sistema, ekonomika, upravleniye 2(49), 24-33 (2020)

16. S. Rayevskiy, Y. Isachenko, Gosudarstvennaya sluzhba 6(92), 12-16 (2014)

17. A.V. Suvorova, Ekonomicheskiye i sotsial'nyye peremeny: fakty, tendentsii, prognoz 12(6), 110-128 (2019)

18. A.P. Sysoyev, Territorial'noye upravleniye. 214 Finansovyye issledovaniya №3(48) (Tatis, M., 2001)

19. A.I. Tatarkin, Ekonomicheskaya nauka sovremennoy Rossii 3, 101-113 (2001)

20. A.I. Tatarkin, Y.V. Perevalov, S.Y. Yurpalov, Ekonomicheskaya nauka sovremennoy Rossii 1, 39-53 (1999)

21. A.A. Urunov, M.M. Avezova, M.A. Nasimova, Vestnik universiteta 5, 161-168 (2020)

22. Z.H. Budevil', Problemy regional'nogo ekonomicheskogo planirovaniya (Edinburg, 1992) 